\author{
Asian Journal of \\ Medical and Biological Research \\ ISSN 2411-4472 (Print) 2412-5571 (Online) \\ www.ebupress.com/journal/ajmbr
}

\title{
Article \\ Prevalence of Salmonella and Escherichia coli contamination in shrimp (Penaeus monodon) farms, depots and processing plants in different areas of Bangladesh
}

\author{
Md. Faridullah, Vikash Chandra Roy* and Ulfat Jahan Lithi \\ Department of Fisheries Technology, Hajee Mohammad Danesh Science and Technology University, Dinajpur- \\ 5200, Bangladesh \\ *Corresponding author: Vikash Chandra Roy, Department of Fisheries Technology, Hajee Mohammad Danesh \\ Science and Technology University, Dinajpur-5200, Bangladesh. Mobile: +880-1722658452; E-mail: \\ vikash.ft05@gmail.com
}

Received: 17 May 2016/Accepted: 14 June 2016/ Published: 30 June 2016

\begin{abstract}
A study was conducted to determine the level of contamination by indicator organisms (Salmonella and Escherichia coli) in shrimp (Penaeus monodon) farms, depots and processing plants of Cox's Bazar, Khulna, Bagerhat and Satkhira districts of Bangladesh using conventional technique of bacterial isolation and identification. The results of this study revealed that prevalence of Salmonella positive samples was $43.7 \%$, $62.5 \%, 20 \%$ and $0.0 \%$ for water, pond scum, shrimp and basket samples, respectively at farm level. Meanwhile, the prevalence of $E$. coli positive samples was $62.5 \%, 43.7 \%, 60 \%$ and $60 \%$ for water, pond scum, shrimp and basket samples, respectively at farm level. In case of depots, shrimp, basket and mat samples were analyzed and found 20\%, 56.3\% and 23\% positive for Salmonella and 53.3\%, 37.5\% and 92.3\% positive for E. coli. Bacteriological assessment of the shrimp samples obtained from four seafood processing plants revealed that all the samples were found contaminated with Salmonella and E. coli except the samples of one industry. Investigation finally showed that with few exceptions all the samples from farms, depots and processing plants have different levels of contamination by Salmonella and E. coli, which is very much alarming for shrimp industry of Bangladesh.
\end{abstract}

Keywords: Penaeus monodon; farms; depots; processing plants; Salmonella; Escherichia coli

\section{Introduction}

Shrimp is considered as 'white gold' for Bangladesh and contributing an important role in national economy. It represents the second largest export industry for Bangladesh after garments with $97 \%$ of the shrimp produced being exported (Kruijissen et al., 2012), contributing about 4\% to national GDP (Haque et al., 2012) and employing approximately 1.2 million people for production, processing and marketing activities.

From harvesting to the consumers table shrimp may be contaminated with various kinds of hazards some of which are natural and others are introduced by the handlers. There are serious safety concerns of raw fish and shell fish due to presence of biological (bacteria, viruses, parasites) and chemical hazards (Hosseini et al., 2004). Salmonellae are gram-negative, non-spore forming motile aerobic rods that characteristically ferment glucose and manose but fail to ferment lactose or sucrose (Jawetz et al., 1982). The natural habitat of Salmonella is the gastrointestinal tract of animals including birds and man (Pelzer, 1989). These organisms find its way into the river water, coastal and estuarine sediments through fecal contamination. Aquatic environment is the major reservoirs of Salmonella and aids its transmission between the hosts (Cherry et al., 1972). The genus Salmonella has a wide variety of species, which are pathogenic and cause different types of food poisoning. Contamination of seafood with Salmonella is major public health concern. The occurrence of Salmonella in fish and shellfish, either in fresh or marine waters has normally been associated with fecal contamination of the area from which they were harvested (Buttaiux, 1962) On the other hand, Escherichia coli, the representative of coliforms, are gram-negative, rod-shaped facultatively anaerobic bacteria. 
Identification criteria used are production of gas from glucose (and other sugars) and fermentation of lactose to acid and gas within $48 \mathrm{~h}$ at $35^{\circ} \mathrm{C}$ (Hitchins et al., 1998). E. coli are naturally found in the intestinal tracts of all warm-blooded animals, including humans. Most forms of the bacteria are not pathogenic and serve useful functions in the intestine. Pathogenic strains of E. coli are transferred to seafood through sewage pollution of the coastal environment or by contamination after harvest. E. coli food infection causes abdominal cramping, water or bloody diarrhea, fever, nausea and vomiting (Ward, 1997) Shrimps Sea foods are usually contaminated by Salmonella and E. coli due to presence of human and animal wastes. Shrimp are also contaminated from the handlers who are not conscious about the hygiene and sanitation during handling of shrimp at different stages. These microorganisms are pathogenic and cause different types of food poisoning. Since importing countries are very much conscious about hazardous pathogens, the importing agencies always reject the shrimp and shrimp products if they contain any Salmonella and E. coli. Therefore, it is very much important to identify the route of Salmonella and E. coli contamination in shrimp farms, depots and processing industry. This study revealed the survey results on the prevalence of Salmonella and E. coli contamination at different shrimp farms, depots and processing plants of some selected areas of Bangladesh.

\section{Materials and Methods}

\subsection{Sampling area and sample collection}

Samples were collected from farms and depots of 8 upazilla under four prominent Shrimp (Penaeus monodon) producing districts of Bangladesh viz. Cox's Bazar, Khulna, Bagerhat and Satkhira. Samples were taken from two farms and two depots from each upazilla. Samples were also taken from the shrimps at the receiving point of four shrimp processing industry located at Cox's Bazar and Khulna. Sources of samples in the farms were water, pond bottom scum, shrimp (body surface, gills and peritoneal cavity), basket (in most cases plastic drums) and mat/polythene sheet. Sources of samples in the depots were shrimp, basket and mat/polythene sheet. Sources of samples in processing industries were only shrimp (body surface, gill and peritoneal cavity). In some of the sampling sites bacterial samples could not be taken from all sources due to practical reasons like unavailability of the sample sources during the time of sampling (Table 1).

Two sampling methods were used such as (i) direct inoculation of samples in pre-enrichment medium and (ii) cotton swabs taken from shrimp, basket and mat/polythene sheet were directly streaked on the surface of Salmonella-Shigella agar (SS agar) plates and the swabs were then inoculated in the pre-enrichment medium. All the samples were shipped to the laboratory within 48 hours of the sample taken. After arrival of the samples in the laboratory, bacteriological analysis was done for the detection of Salmonella sp. and E. coli according to the method of American Public Health Association (Association of Official Analytical Chemists, 1984).

\subsection{Screening and biochemical tests}

A suspected colony of Salmonella was picked up with inoculating loop and inoculated in the Triple Sugar Iron (TSI) agar slant by streaking the slant and stabbing the butt and incubated at $35^{\circ} \mathrm{C}$ for $24 \mathrm{hrs}$. Salmonella cultures typically produce an alkaline (red) slant and acid (yellow) butt, with or without production of $\mathrm{H}_{2} \mathrm{~S}$ (blackening of butt) in TSI agar. The TSI cultures were purified by streaking onto McConkey's agar (MCA) and incubated for $24 \mathrm{hrs}$ at $35^{\circ} \mathrm{C}$. Typical colonies appear transparent and colorless, sometimes with a dark center (Figure 1). For E. coli pink colonies on SS agar were streaked onto Eosine Methylene Blue agar (EMB) and incubated at $35^{\circ} \mathrm{C}$ for $18-24$ hrs. Suspected E. coli colonies had black or dark center with the greenish metallic sheen (Figure 2).

Salmonella and E. coli colonies were sub-cultured in nutrient broth and are incubated at $35^{\circ} \mathrm{C}$ for $24 \mathrm{hrs}$. Using the nutrient broth culture as inoculums the biochemical tests were performed using fresh bacterial culture (Table 2).

\section{Results and Discussion}

\subsection{Contamination in shrimp farms}

The level of Salmonella and E. coli contamination in different samples (water, scum, shrimp, basket and mat) collected from Shrimp farms of different sampling sites of Bangladesh were different.

\subsubsection{Water samples}

Water samples collected from Chokoria, Teknaf, Mongla, Koira and Munshigonj Shrimp (P. monodon) farms have shown positive result in Salmonella test and farms of other three locations Rampal, Paikgacha and Ashashuni have shown negative results. About $43.7 \%$ of the water samples were Salmonella positive. In case of E. coli water samples from all the locations except Paikgacha have shown the positive result and about $62.5 \%$ of the samples have shown the positive result. 
Table 1. Total number of samples collected and number of samples found Salmonella and E. coli.

\begin{tabular}{|c|c|c|c|c|c|c|c|}
\hline \multirow[b]{2}{*}{ Bacteria } & \multirow[b]{2}{*}{ Type of Sample } & \multicolumn{3}{|c|}{ Farm } & \multicolumn{3}{|c|}{ Depot } \\
\hline & & $\begin{array}{l}\text { No. of } \\
\text { sample }\end{array}$ & $\begin{array}{l}\text { No. of } \\
\text { sample } \\
\text { positive }\end{array}$ & $\begin{array}{l}\text { Percent of } \\
\text { positive }\end{array}$ & $\begin{array}{l}\text { No. of } \\
\text { sample }\end{array}$ & $\begin{array}{l}\text { No. of } \\
\text { sample } \\
\text { positive }\end{array}$ & $\begin{array}{l}\text { Percent of } \\
\text { positive }\end{array}$ \\
\hline \multirow[t]{5}{*}{ Salmonella } & Water & 16 & 7 & 43.7 & - & - & - \\
\hline & Scum & 16 & 10 & 62.5 & - & - & - \\
\hline & Shrimp & 30 & 6 & 20.0 & 45 & 9 & 20.0 \\
\hline & Basket & 10 & Nil & 0.0 & 16 & 9 & 56.3 \\
\hline & Mat & 6 & Nil & 0.0 & 13 & 3 & 23.1 \\
\hline \multirow[t]{5}{*}{ E. coli } & Water & 16 & 10 & 62.5 & - & - & - \\
\hline & Scum & 16 & 7 & 43.7 & - & - & - \\
\hline & Shrimp & 30 & 18 & 60.0 & 45 & 24 & 53.3 \\
\hline & Basket & 10 & 6 & 60.0 & 16 & 9 & 56.2 \\
\hline & Mat & 6 & Nil & 0.0 & 13 & 12 & 92.3 \\
\hline
\end{tabular}

Table 2. Biochemical tests for phenotypic characterization of Salmonella and E. coli.

\begin{tabular}{llll}
\hline Tests $($ Salmonella $)$ & Results & Tests $($ E. coli) & Results \\
\hline Catalase & + & Catalase & + \\
Cytochrome oxidase & - & Cytochrome oxidase & - \\
MR & + & MR & + \\
VP & - & VP & - \\
Indole & - & Indole & - \\
Citrate & $+/$ & Citrate & \\
KCN & - & & \\
Malonate & - & & \\
Urease & - & & \\
Lactose & - & & \\
Sucrose & - & & \\
\hline
\end{tabular}

The tests were incubated at $35^{\circ} \mathrm{C}$ for $18-24 \mathrm{hrs}$.

Table 3. Incidence of Salmonella and $E$. coli contamination in selected shrimp ( $P$. monodon) processing plants (at receiving point) of Bangladesh.

\begin{tabular}{llllll}
\hline Bacteria & Sample & $\begin{array}{l}\text { Conception Seafood, } \\
\text { Cox's Bazar }\end{array}$ & $\begin{array}{l}\text { Kuliarchar Seafood, } \\
\text { Cox's Bazar }\end{array}$ & $\begin{array}{l}\text { Rupsha Seafood, } \\
\text { Khulna }\end{array}$ & $\begin{array}{l}\text { Fresh Seafood, } \\
\text { Khulna }\end{array}$ \\
\hline \multirow{3}{*}{ Salmonella } & Shrimp & + & + & - & + \\
& Basket & $*$ & $*$ & $*$ & $*$ \\
\multirow{4}{*}{ E. coli } & Mat & $*$ & $*$ & $*$ & $*$ \\
& Shrimp & + & + & + & + \\
& Basket & $*$ & $*$ & $*$ & $*$ \\
\hline
\end{tabular}

* Sample could not be taken
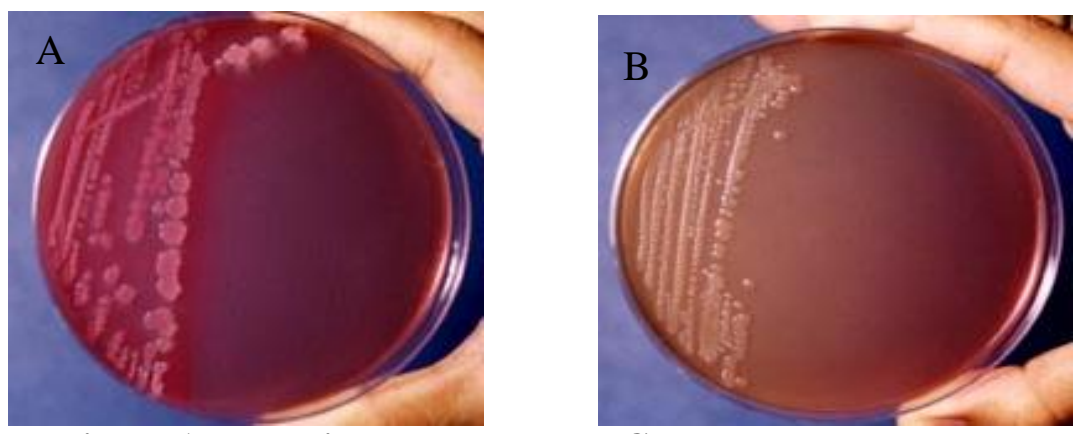

Figure 1. Bacterial growth on MacConkey agar.

A. Escherichia coli on MacConkey agar: growth, pink color colonies

B. Salmonella on MacConkey agar: growth, colorless colonies 


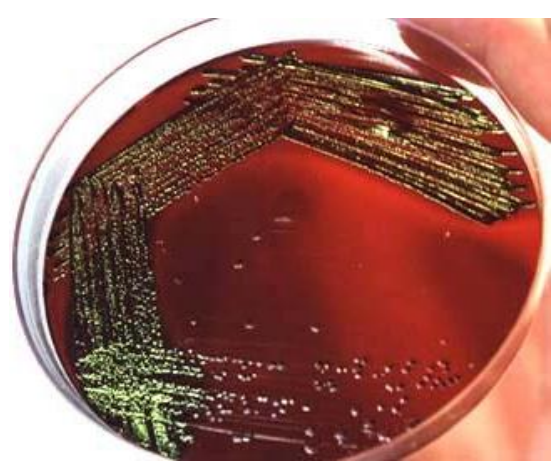

Figure 2. Escherichia coli on EMB agar with metallic sheen.

\subsubsection{Pond bottom scum}

Scum samples from all the locations except Paikgacha have been found Salmonella positive. About 62.5\% of the scum samples have been tested positive for Salmonella. On the other hand scum samples from Chokoria, Rampal Mongla, Munshigonj and Ashashuni have been tested positive for E. coli and samples from other three locations Teknaf, Paikgacha and Koira tested negative. About $43.7 \%$ of the samples have been tested E. coli positive.

\subsubsection{Shrimp}

Shrimp samples of both the farms of Chokoria and Teknaf and one farm of Rampal have been tested Salmonella positive and samples from the farms of other locations tested Salmonella negative. $20 \%$ of total shrimp samples have been tested Salmonella positive. On the other hand shrimp samples collected from the farms of all the locations have been tested $E$. coli positive. $60 \%$ of all the shrimp samples have been tested E. coli positive.

\subsubsection{Baskets and mats/polythene sheet}

Samples taken from baskets and mats from Shrimp farms have been tested Salmonella negative. However, due to unavailability of baskets and mats samples could not be taken from some farms. Samples taken from the baskets found in the farms of Teknaf, Rampal Munshigonj and Ashashuni were E. coli positive but the samples taken from the mats were $E$. coli negative. $60 \%$ of basket samples tested were $E$. coli positive.

\subsection{Contamination in shrimp depots}

The bacteriological assessment of different samples obtained from different shrimp depots of different areas revealed different level of Salmonella and E. coli contamination.

\subsubsection{Shrimp}

Shrimp samples from at least one depot of each sampling location have been tested Salmonella positive except Paikgacha where samples collected from both the depots were Salmonella negative. Bacteriological samples collected from the depots of all the locations have been tested E. coli positive except Koira where samples from both the depots were E. coli negative. $20 \%$ of all the samples were Salmonella positive. On the other hand $53.3 \%$ of all samples were tested E. coli positive.

\subsubsection{Basket}

Bacteriological samples collected from the baskets of at least one depot of each sampling location were tested Salmonella positive and except one location (Teknaf) samples collected were E. coli positive. Among the samples $56.2 \%$ were Salmonella and E. coli positive.

\subsubsection{Mat/polythene sheet}

Bacteriological samples collected from the mats/polythene sheet used in the depots of Mongla, Paikgacha and Koira were Salmonella positive. About 23\% of the samples collected have been tested Salmonella positive. On the other hand almost all the samples collected from the mats of all the depots have been tested E. coli positive. 


\subsection{Contamination in processing plants}

Bacteriological samples were collected from shrimps at the receiving point of 4 processing plants of Cox's Bazar and Khulna region. Except Rupsha Seafood Industry of Khulna all the shrimp samples were found contaminated with Salmonella and E. coli (Table 3).

Present study conducted on the incidence of Salmonella and E. coli in Shrimp from different sources like culture ponds (water, scum), containers (mat, polythene sheet, basket/tanks etc.) transport and other sources related to post-harvest handling and transportation of shrimp. Results found are comparable to previous studies conducted elsewhere. But no information is available on Bangladesh.

A number of researchers studied the Salmonella and E. coli contamination in seafoods particularly in penaeid shrimps ( $P$. monodon). The coliform contents of farmed penaeids varied between 460-1100 whereas the surrounding water and sediments were between $11 \times 10^{3}$ and 123 or 1100 respectively. Faecal coliforms were found in the range of 10-200 on the sediment samples (Putro et al., 1990). Coliform bacteria, Escherichia coli, coagulate-positive staphylococci, Salmonella, and Listeria monocytogenes contamination was studied in individually quick frozen (IQF) shrimp products. S. typhimurium was isolated from one sample of raw, peeled tail-on. Coliforms were detected in all the products, though at a low level. Prevalence of coliforms was higher in headless shell-on (26\%) shrimps followed by raw, peeled, and deveined tail-off (19\%), raw, peeled tail-on (10\%), and cooked, peeled tail-on (3.8\%) shrimps. The highest prevalence of E. coli $(4.8 \%)$ was noticed in headless shell-on shrimps. Overall results revealed that the plant under investigation had exerted good process control in order to maintain superior bacteriological quality of their products (Hatha et al., 2003). Occurrence of Salmonella in fish and shellfish, either in fresh of marine waters has normally been associated with fecal contamination of the area from which they were harvested (Buttaiux, 1962). Thus it is generally suggested not to use animal manure as a source of fertilizer for aquaculture ponds because this practice introduces Salmonella which was later isolated from the harvested product (Miget, 1991).

In the present study it was found that about $70 \%$ farms received from and drain out water to another pond in all survey areas. Although the use of organic manure like cow-dung or chicken waste is limited in the ponds but there is a chance of contamination of the water with sewage through the water receiving canal from other sources. Introduction of Salmonella and E. coli to the water and scum as well as shrimp samples of farms may due to the above reasons.

Post process contamination can occur by coliforms, fecal coliforms including E. coli, Staphylococcus and Salmonella to the raw materials particularly when significant hand peeling is involved (Miget, 1991). Pathogens also introduced via product handlers-from personnel on the harvest boat, through processing plant and food service handlers, and ultimately the consumers. The hands of workers have been identified as sources of these pathogens .In the present study, the percentage of Salmonella and E. coli contamination to the samples from depots was higher than those from farms may due to improper and rough handling, delay icing, improper washing, careless beheading and peeling of the shrimps.

\section{Conclusions}

Detection of Salmonella and E. coli in samples collected from pond water and scum indicates various degrees of contamination and pollution. The same organisms detected in baskets, mats and shrimp indicate the poor sanitation and hygienic conditions of farms. Isolation of Salmonella and E. coli in the depots indicates the poor infrastructure facilities, poor sanitation and contamination in the depots. Most of the Shrimp farms are located nearby villages and the farms are ultimate recipient of community disposal including human and animal excreta, which may carry potential pathogens. This must be stopped. The incidence of disease in Shrimp farms is very frequent. Good farming practice including regular water quality monitoring is important to tackle the problem. Training programs are required for farmers, suppliers and depot owners for implementation of HACCP at the field level for effective quality management.

\section{Acknowledgements}

We are grateful to our respected teachers Professor Dr. Md. Kamal and Professor Dr. Md. Nazrul Islam from the Faculty of Fisheries, Bangladesh Agricultural University for their cordial help during research. We are also grateful to Shrimp Foundation Dhaka, Bangladesh for their funding for this research work.

\section{Conflict of interest}

None to declare. 


\section{References}

AOAC. 1984. Official methods of analysis. Association of Official Analytical Chemists, $13^{\text {th }}$ edition, Washington, USA.

Buttaiux R. 1962. Salmonella problems in the sea, In: Borgstrom, G. (ed), Fish as Food, Academic Press, New York. p.503.

Cherry WB, JB Hanks, BM Thomason, AM Murlin, JW Briddle and JM Croom. 1972. Salmonellae as an index of pollution of surface waters. Applied Microbiology 24: 334-340. Hatha AAM, TK Maqbool, SS Kumar. 2003. Microbial quality of shrimp products of export trade produced from aquacultured shrimp. International-Journal-of-Food-Microbiology 82: 3, pp. 213-221.

Haque MM, MA Wahab, DC Little, FJ Murray 2012. Development trends and sustainability issues of four commercially important farmed seafood trade in Bangladesh. Bangladesh Agricultural University: SEAT working paper. pp. 35-55.

Hitchins AD, P Feng, WD Watkins, SR Rippey and LA Chandler. 1998. Escherichia coli and the coliform bacteri. Ch. 4. In Food and Drug Administration Bacteriological Analytical Manual, $8^{\text {th }}$ ed. (revision A). (CD-ROM version), R.L. Merker (ed.). AOAC, International, Gaithersburg, MD.

Hosseini H, AC Majid, R Yalfani, and V Razavilar. 2004. Incidence of Vibrios spp. in shrimp caught off the south coast of Iran. Food Control 15: 187-190.

Jawetz E, JL Melnick and EA Adelberg, 1982. Review of Medical Microbiology, LANG Medical Publications, California. p. 234.

Kruijissen F, K Ingrid, MC Hong, J Karen, J Stefano, 2012: Value Chains of Selected Aquatic Products from four Asian Countries, A review of literature and secondary data (draft version). pp. 4-12.

J Milner, 1996. LFRA Microbiology Handbook, Leatherhead UK. pp.1-53.

Miget RJ, 1991. Microbiology of crustacean processing: shrimps, crawfish and shrimps. Microbiology of marine food products. pp. 65-68

Pelzer KD, 1989. Salmonellosis. J. of Veterinary Medical Association. pp. 456-463.

Putro S, AM Anggawati, YN Fawxya and F Ariyani, 1990. Studies on microbiology of farmed shrimp. Indo-Pacific Commision. Papers presented at the Seventh session of the Indo-Pacific Fishery Commission Working Party on fish Technology and marketing. Bangkok, Thailand. 19-33, April 1988. No. 401 Suppl. pp.6-1.

Ward D, D Bernard, R Collette, D Kraemer, K Hart, R Price and S Otwell. (Eds.), 1997. Hazards Found in Seafoods, Appendix III. In HACCP : Hazard Analysis and Critical Control Point Training Curriculum, $2^{\text {nd }}$ ed., p. 173-188. UNC-SG-96-02, North Carolina Sea Grant, Raleigh, NC.

Ward DR, and AC Hackney, 1991. Microbiology of marine food products. Van Nostrand Reinhold, New York. 